\title{
Mental Health Review Tribunals and the Council on Tribunals
}

\author{
Carole A. Kaplan
}

\begin{abstract}
Mental Health Review Tribunals (MHRTs) are independent quasi-judicial bodies which operate under the Mental Health Act 1983. They are placed under the supervision of the Council on Tribunals. There is justifiable current interest in the need to ensure that the performance of MHRTs is open to fair but critical examination (Langley, 1993; Saad \& Sashidharan, 1992). This article describes the supervisory role undertaken by the Council on Tribunals in this area, and their current interest in the working and procedures of MHRTs.
\end{abstract}

\section{The Council on Tribunals}

The Council were set up by the Tribunals and Inquiries Act 1958 following the Report of the Committee on Administrative Tribunals and Enquiries (the Franks Committee) in the previous year. They now operate under the Tribunals and Inquiries Act 1992, and are essentially an advisory body wholly independent of any government department or of any tribunal system.

The Council consist of between ten and 15 members who are part-time and are appointed by the Lord Chancellor and the Lord Advocate. Their principal functions are to keep under review the constitution and working of tribunals and to consider and report on statutory inquiries. Approximately 70 tribunal systems, including MHRTs, have been brought under the Council's supervision. The Council have to be consulted on all procedural rules for tribunals under their supervision, and on procedural rules made by the Lord Chancellor in connection with statutory inquiries. They are also consulted on legislation relevant to their interests and on proposals for new adjudicative procedures. However, their purview goes much wider. They take a keen interest in anything which relates to the way tribunals and inquiries operate. For example, eliminating delays, ways in which tribunals can demonstrate their independence, guidance literature for parties, the qualification of tribunal chairmen and members, the role of clerks, hearing accommodation and other resources. They also pay attention to the issues of training for tribunal chairmen and members and advice and representation for parties, including legal aid.

The Council invite Presidents and Chairmen of tribunals, Departmental officials and, occasionally, Ministers for discussions about matters of common concern. They are required to make an Annual Report which is published as a House of Commons Paper.

\section{How they operate}

As part of their supervisory function, Council members make about 150 visits each year to a wide variety of tribunals and inquiries. This vital element of their work gives individual members a practical knowledge and understanding of the tribunals they supervise. If tribunal members or staff have concerns about any aspect of their jurisdiction, or the conditions in which they work, Council members hear about them in the course of their visits. At the conclusion of each visit, the member makes a confidential report to the Council.

\section{The Council's interest in MHRTs}

MHRTs are among the larger tribunal systems over which the Council exercise a supervisory jurisdiction, and they are included in the few they supervise whose decisions bear directly on the liberty of the person. Recent Annual Reports have commented on a number of features of MHRTs.

\section{Hearing delays}

The Mental Health Act 1983 created a substantial additional workload for MHRTs. According to the Department of Health, the number of new applications has risen sharply, 
by over $135 \%$ since the Act came into force; in particular, unrestricted cases have risen by $170 \%$ over the period, and section 2 cases by $200 \%$. The increase has caused widespread delays in the time taken to arrange hearings for section 3 and restricted cases, and the Council have drawn attention in successive Annual Reports to their growing concern about the problem. That concern, it may be noted, is confined to the position in England and Wales. In Scotland, appeals are dealt with by the Sheriff Courts without delay.

The rapid rise in applications since 1983 has been accompanied by significant changes in the length and complexity of cases. A substantial increase in priority section 2 cases, now approaching 3,000 a year, has restricted the ability of the tribunals to handle other applications with due efficiency. There has also been a marked increase in the number of cases in which patients or their representatives request an independent psychiatric report (IPR). In the London region alone, the impression is that reports are being requested in some $40 \%$ of restricted cases compared with around $10 \%$ in 1990 . In addition, a great number of restricted cases are being held outside the special hospitals, calling for a greater range of sites on which to hold tribunal hearings, leading to organisational problems.

As recorded in their recent Annual Reports, the Council have held a series of detailed discussions with officials from the Department of Health about the problem. Delays are caused by a combination of factors. Some fall within the power of the tribunals themselves to rectify, such as a lack of appropriate staff in the Regional Offices to service tribunal hearings, inadequate training or poor administrative practices. These are a matter for direct action, either by the tribunal or the Department concerned, and, by and large, the Department have reacted, and continue to react, positively to suggestions for improvements in each of these areas. Further staff have been recruited, in particular to service the fourth Regional Office which was opened in London in 1992. But the impression gained by Council members during the course of their more recent visits to MHRTs is that further action is necessary in this area, and they have asked the Department to keep staffing levels under continuous review. The Department are also taking steps to minimise delays by closer management control, more standardised procedures in the Regional Offices, and by reviewing the targets set for disposing of different types of cases. They are now working closely with MHRT Regional Chairmen with the aim of improving arrangements for training.

Other factors are outside the ability of the tribunal to control directly, although their effect on delays may be no less significant; for example, the action or inaction of the parties or their representatives, including the use made of independent psychiatric reports (IPRs), as well as the way in which the respective duties are carried out by responsible medical officers (RMOs), social workers, hospital managers, the Home Office and others concerned in the tribunal process. The Council have commented on acute problems in each of these areas in recent years, and they welcomed the Department's decision two years ago to commission detailed research into the pattern and causes of delay at MHRTs in an effort to establish what effect these factors are having on delays. The outcome of that research was presented to the Department towards the end of last year, and the report was published by them in December (Blumenthal \& Wessely, 1993; 1994). The Council have asked the Department to inform them of the action they propose taking to address the various problems which have emerged.

There are also concerns about the problems which arise in relation to the preparation of reports by RMOs and social circumstances reports. The Council have been concerned for some time about the difficulties caused to MHRTs by the submission of reports outside the three week time limit set by the MHRT Rules $^{1}$. A few years ago they approached each of the regional health authorities about the matter, in order to establish the nature of the problems which, from their own perspective, might lead to delays and to seek their views on whether a solution could be found. The Council welcomed the ideas put forward by a number of RHAs for tackling some of the difficulties which they had identified. The information was passed to the Department. who agreed to take action in a number of areas which they hoped would lead to improvements.

${ }^{1}$ Rule 6 of the Mental Health Review Tribunal Rules 1993. 
Much of what the recent research has to say about the reasons for delays in the preparation of RMO and social circumstances reports reinforced the Council's own findings following their earlier initiative. They include the volume of Mental Health Act work, particularly in special hospitals, and the pressures caused by the nature and timing of section 2 cases: the competing priorities faced by RMOs in relation to their clinical and other duties, a shortage of staff qualified to give reports, and problems associated with locum cover, annual leave and sickness; the fact that reports completed on time can frequently be out-of-date by the time of the hearing; and the belief that three weeks must be regarded as insufficient to prepare a good report in complex cases.

Beyond the action which the Department will be taking to address these issues, the Council have themselves considered whether some mechanism can be found which might lead to a reduction in the time given by RMOs and others to the task of preparing reports. It may be that there is scope for improving the guidance given to those who are required to undertake the task.

\section{Independent psychiatric reports}

The Council have also considered what the research findings reveal about the close association between the fact of patient representation and the use of IPRs and adjournments, and their significant influence on delays at MHRTs. It is evident that IPRs substantially increase the length of time to the hearing. On the other hand, in cases in which they support discharge, IPRs are shown significantly to increase the likelihood of discharge. Care has to be taken, therefore, in deciding how best to strike the right balance in an effort to keep delays to a minimum. This is largely a question of procedural control, and the Council have suggested to the Department that there may be a case for increasing the use made of interlocutory hearings, to enable the MHRT Chairman to establish what is happening and who is doing what, and to give any necessary directions about the conduct of the case. Indeed, the Chairman's interest could extend beyond the actions of the patient's representative and the commissioning of the IPR, to the progress being made on the hospital statement and any special factors which may come to light in the RMO's report which are likely to have a bearing on the final decision of the tribunal.

The research mentions the apparent difficulties which representatives have in commissioning an IPR, particularly in the more complicated and specialised forensic cases, and the causal link this has with adjournments. Again, in order to address the particular difficulties which arise, the Council have given their support to the idea of a register of panel doctors to which patients' representatives could turn when necessary, and they have invited the Department to look into the matter.

Finally, the Council have recently pressed the case with the Department for a move away from the current regional structure of MHRTs to a presidential system of organisation. But as yet, Ministers have not felt persuaded by the case for making available the additional resources such a change would require.

In a matter affecting the liberty of the subject, the current level of delays cannot be regarded as acceptable. It is imperative that the rights given to patients by the 1983 Act to challenge their detention over each successive prescribed period can be exercised effectively. As matters currently stand, many patients are still not being given the decision on the correctness of their detention until the whole or a greater part of it has expired.

\section{The manager's review}

This is a different procedure from referral to a MHRT and managers are responsible for ensuring that patients know the difference. It is important that no impression is given that a manager's review must precede a MHRT, or that a request for a manager's review negates the right to apply for an MHRT (Code of Practice, Mental Health Act 1983). Managers must ensure that any patient who wishes to apply to an MHRT is given all necessary assistance to do this. Under section 68 of the 1983 Act, managers are obliged to refer certain patients to MHRTs. However, managers have the power to discharge certain categories of detained patients and these reviews and decisions are completely independent of MHRTs, and therefore outside the remit of the Council on Tribunals.

\section{The media}

Other topics which have exercised the Council in the past include the extent to which MHRTs 
need protection against prejudicial comment and disclosure by the media and others pending a hearing. Their concern about this issue stemmed from a case in 1985 in connection with a restricted patient whose application for release from a mental hospital was due to be heard by a tribunal. Reports in the press of a Minister's comments led to the adjournment of the case for three months. The Minister concerned attended one of the Council's meetings and this led in due course to the Home Office agreeing that, other than in exceptional circumstances, Ministers would not make any substantive comment liable to affect a case during the four weeks preceding the hearing. After various vicissitudes, the case eventually went to the House of Lords ${ }^{2}$, which held that MHRTs are courts to which the law of contempt applies. This means that they are covered by the Contempt of Court Act 1981.

\section{Legal aid}

The Council have long pressed the case for adequately funded advice and representation for parties to tribunal proceedings. They warmly welcomed the extension of legal aid, in the form of Assistance By Way of Representation to MHRTs in 1982, and are pleased to note that amending Regulations, which came into force in April 1994, now provide for this to be made available without reference to a patient's financial means.

\section{The cost of MHRTs}

According to the first Annual Report of Mental Health Review Tribunals for England (covering the 12 months to December 1993), the provision made by the Department of Health for running the tribunal service in the financial year $1993 / 94$ was $£ 4,503,415$. The costs associated with the MHRT system as a whole were put at $£ 12,274,380$ in 1983 (Blumenthal \& Wessely, 1993).

\section{Conclusion}

It is hoped that this brief summary of the Council's role, and the way it is being exercised in relation to the working of MHRTs, will go some way to clarify the extent to which this

${ }^{2}$ Pickering \& Liverpool Daily Post and Echo Newspapers plc and others [1991] I All E.R.622. important tribunal system is open to continuous and critical scrutiny. The Council welcome comments and suggestions for improvements in the constitution and working of the tribunals they supervise. Although they have no powers in relation to individual cases, they attach great importance to the experience they glean from their visits to tribunals, and to the information they receive from a variety of sources, including those concerned in proceedings before tribunals. There will inevitably be occasions when those involved in the proceedings of MHRTs will find that a Council member is in attendance at the hearing. Whenever that is the case, please do not hesitate to make your views known to the member concerned.

\section{Acknowledgements}

I am grateful to Mr Paul Ralph of the Council on Tribunals who has provided guidance and major assistance in the production of this article. I also thank Mrs Sally Friend for her helpful comments.

\section{References}

Blumenthal, S. \& Wessely, S. (1993) The Pattern of Delays in Mental Health Review Tribunals (Summary). Published by HMSO. See also the article by Blumenthal. S. \& Wessely. S. Psychiatric Bulletin (1994) 18. 398-400.

LANGLEY, G. E. (1993) Mental Health Review Tribunals in practice. Psychiatric Bulletin. 17, 331-336.

SAAD, K. F. G. \& SASHIDHARAN, S. P. (1992) Mental Health Review Tribunals. Psychiatric Bulletin, 16, 470-472.

\section{Addendum}

The current members of the Council on Tribunals are Lord Archer of Sandwell, PC, QC, Chairman; T Norman Biggart, Esq, CBE, WS; Mrs Annie Anderson; G A Anderson, Esq, CA, FCMA; M B Dempsey, Esq; Mrs S Friend, JP; Christopher Heaps, Esq; B Hill, Esq, CBE, DL; Professor M J Hill; W N Hyde, Esq; R H Jones, Esq, CVO; Dr C A Kaplan; Professor T M Partington; I D Penman, Esq, CB; Lionel Read, Esq, QC; and W K Reid, Esq, CB (ex officio as Parliamentary Commissioner for Administration).

Carole Kaplan, Senior Lecturer in Child and Adolescent Psychiatry, Fleming Nuffield Unit, Department of Child Health, University of Newcastle Upon Tyne. Member of the Council on Tribunals 